Pre-peer-review version of paper published 'on-line early' in Journal of Philosophy of Education on July 12015 . The published version has benefited greatly from reviewers' comments.

Please consult the revised version if you wish to cite this paper.

\title{
Abstract
}

This paper is a critical discussion of two recent papers by Michael Hand on moral education. The first is his 'Towards a theory of moral education', published in the Journal of Philosophy of Education in 2014 (Volume 48, Issue 4). The second is a chapter called 'Beyond Moral Education?' in an edited book of new perspectives on my own work in philosophy and history of education, published in the same year. His two papers are linked in that he applies the theory outlined in the former to a critique in the latter of my views on education in altruism in a 1990 publication. I introduce this paper by outlining the tradition of recent philosophical thought about moral education, beginning with that of Richard Peters, in which Hand is working.

\section{Moral education and education in altruism. Two replies to Michael Hand}

John White

UCL Institute of Education

Michael Hand published a theory of moral education in a recent article in this journal (Hand 2014b). In the same year, he contributed a chapter to a book of new perspectives on my work, in which he criticised my 1990 account of education in altruism in the light of his new theory (Hand 2014a). In my present paper I discuss both of his essays, beginning with the one setting out the theory.

1. Hand's theory of moral education 
The practical problem that Hand sees his theory as helping to solve is this. Children have to be morally educated, but 'morality is controversial: there is deep uncertainty about both the requirements of morality and the reasons to comply with them.' (Hand 2014b: 521). This makes moral education seem tantamount to indoctrination. Hand's solution is, broadly, to locate an area of morality that is, after all, non-controversial and can thus be at the centre of a non-indoctrinatory kind of moral education.

He finds this area in the sphere of moral rules. Although there might be other elements in moral education like the cultivation of virtues such as patience or temperance (525), a central task is education in and about moral standards. Both of these elements are necessary. Hand labels them 'moral formation' and 'moral enquiry'. It is not enough for children to learn to be dispositionally inclined to follow moral standards and expect others to do so, too: they must also believe that they have good reasons for doing these, are justified in so doing. 'Moral enquiry' is that part of the teacher's work that engages children in investigating whether and which moral standards are justified (526).

Moral enquiry can take two forms. It is 'directive' 'when a teacher has the aim of persuading children that moral standards under investigation are, or are not, justified'; 'non-directive' when standards are controversial and the teacher's job is to present them as such. Hand's main interest is in the directive kind. Sometimes the teacher has to lead children to see the unjustifiability of certain moral beliefs, e.g. that homosexual acts are wrong. But his or her more central purpose is to bring students to accept the justifiability of moral standards that are incontrovertible, assuming that any such standards exist.

The core of Michael Hand's paper is an argument that there are indeed such things, and that these consist in a small number of 'basic moral standards' on which there is broad consensus in society. These cover 'prohibitions (on stealing, cheating, causing harm, etc.) and prescriptions (to treat others fairly, help those in need, keep one's promises, etc.)' (528). The justification for these is found in H.L.A. Hart's well-known argument for 'the minimum content of natural law' in Hart 1961, deployed also by later writers down to David Copp (2009). ${ }^{1}$ In Hart's 
version, this is that, human beings and their circumstances being what they are in any society, these basic rules are necessary for social survival. Since we are all physically vulnerable, for instance, there have to be prohibitions on killing and on bodily harm. It is because resources required to satisfy our basic needs for food, shelter, etc. are limited, that any society has to have property rules and prohibitions against stealing. As Hand writes: 'Since all of us who live in social groups have an interest in averting breakdowns of cooperation and outbreaks of conflict, so we all have an interest in holding ourselves and others to rules of conduct that sustain cooperation and peace' (529).

In helping children to understand this, Hand argues, teachers supply them with good reasons for following these basic moral standards. When they teach in this way, moral education can be fully rational, and indoctrination can be avoided.

\section{Discussion of Hand's theory}

(a) Scope

At first sight, Hand's theory may seem excessively restricted. It may appear to say that the only moral precepts that children may justifiably be taught to follow are 'don'ts' - don't lie, don't kill, don't act unfairly, don't break your promises, etc. But this would be a mistake. For his list of examples also includes 'help those in need'. This immediately turns what might have been a very minimal set of moral expectations into one of potentially boundless scope.

If the first, unrelievedly negative, set of standards exhausts our moral duties, we can spend virtually the whole of our lives on our own pleasures and private pursuits, reducing bonds with other people, if we will, to nothing. All we have to do is take good care that we do not kill or maim anyone (not too difficult), do not lie or break a promise (sometimes hard to avoid, but manageable or get-round-able), do not give ourselves unfair advantages over others (ditto), and so on. 
But once 'help those in need' is added to the list, the moral shape of our lives may well be dramatically transformed. For the number of people in need - whether out of poverty, physical or mental disability or illness, lack of education, becoming an orphan or a refugee, or for any number of other reasons - is vast. This is so even on a national scale, and far more so globally. If we have a moral duty to help those people tout court, discharging it could well take up virtually most of our lives. Far from having all the time in the world for our own private pursuits as on the earlier scenario, we could be left with little or none at all.

This indeterminacy in Hand's account of basic moral standards will be lessened if we interpret 'help those in need' as the familiar moral injunction not to turn one's back on anyone in one's immediate vicinity who is in distress - a person, for instance, who has just been knocked off her bike. This clarifies things - but at the cost, if it is a cost, of having once again to retreat to a moral minimum. For like rules against stealing or cheating, this rule is likely to make few demands on personal time.

A further point about helping those in need (or distress) is that it is not altogether clear whether it properly belongs to the class of basic moral standards for Hart-like reasons. Continued social existence (or absence of serious social conflict, as in Copp's (2009) formulation) would indeed be massively imperilled if there were no sanctions against killing or stealing or breaking promises. But I cannot see that this has to be true of not helping others in trouble. One can imagine a society that brings its children up to be maximally self-reliant, prepared to suffer if things go badly amiss, and not to expect others to help them. I don't know if Hart himself had anything like this in mind, but it may be noteworthy that all his examples are of what he calls 'forbearances' - of things we are not to do rather than positive behaviour like helping others. He talks, for instance, of 'the system of mutual forbearances which underlies both law and morals' (Hart 1961: 195).

(b) Justification

So much for matters to do with the scope of basic moral standards. I now turn to something more central. The great significance, for Hand, of Hart and his followers' basic standards is that these, and it seems these alone, 
are capable of the kind of incontrovertible justification he is looking for. But is it so clear that the alleged justification is indeed so trouble-free or, more radically, that it is a justification at all?

It states, to remind us, that in the light of facts about human nature and the circumstances in which any human beings live, there have to be moral prohibitions of killing, stealing and the like for a society, or a peaceful society, to be viable. On the face of it, this does not seem to be a valid argument, if taken as a justificatory one. It seems to claim that killing (etc) is morally wrong because of facts about human nature; and thus to be a naturalistic argument, open to the familiar objection that it argues illicitly from what is the case to what ought to be the case. The whole statement looks like an empirical claim. It seems to be putting forward an explanation of why we have rules against killing (etc), rather than a justification of them.

But this objection is misconceived. Hart himself is at pains to point out that he is not dealing with a causal explanation (pp.189-90). As he sees it, if we begin from the - reasonable - assumption that society should continue to survive, the preconditions of its continuing survival also have to be in place, and these include the moral prohibitions in question (p.188).

The argument is not invalid. It does not deduce a normative conclusion from empirical premises, since it derives this from what is itself a normative proposition, that society should continue to survive.

A stickler for justifications might, of course, press further and ask why there should be continued survival. Might not someone jaundiced about what they see as the failures of the human race think it better - for religious, ecological or other reasons - if it died out? Maybe. But if the survival sceptic were able to produce a valid argument in favour of nonsurvival, their basic premise would still have to contain an 'ought' or a 'good', and thus invite a further demand for reasons. To rule out an infinite regress, justifications have to start somewhere. Michael Hand follows Copp's version of the Hart argument in taking the desirability of continued social existence free of major conflicts as his starting point. 
This does not, of course, exclude the possibility of taking other considerations as one's point of departure in justifying a moral claim. This causes difficulties for Hand's theory, as we shall see once we have reminded ourselves of its role in moral education.

Hand holds that 'to help children understand' this justification 'is to supply them with good reasons for subscribing to at least a subset of the moral standards current in society. It follows that directive moral education can be fully rational, insofar it is restricted to endorsement' of the justification in question. 'Children can be educated for full moral commitment without recourse to indoctrination' (529).

There are various issues here: [a] a minor one about indoctrination, and [b] weightier ones about supplying reasons to children.

[a] Hand's understanding of indoctrination connects it with the supplying or non-supplying of good reasons, eg for a moral standard. Indoctrination can be avoided, as we have seen, if good reasons are given (the Hart inspired argument, in the case of moral standards). If no reasons are given at all as in some sorts of moral formation, Hand seems to suggest that indoctrination may also be avoidable (pp. 526-7). A clear-cut case of it 'would be involved in any attempt to make children believe that there are good reasons for subscribing to a moral code when in fact there are not.' But this would seem to make many a teacher who unknowingly gives children inadequate reasons for a belief an indoctrinator.

This goes against how the term is standardly used - that is, with the implication of trying to prevent reflection on a belief. An indoctrinator into a religious or political belief - that God made the world, or that the Great Leader can do no wrong - tries, for instance, to isolate pupils from contact with those who might cause them to challenge this. Methods of isolation can include separate schooling with a school ethos that reinforces certain taken-for-granted beliefs; control of the internet; punishment for associating with sceptics or disbelievers; surrounding the teacher with an aura of infallibility. As far as I can see, it would in principle be possible to indoctrinate people in the belief that Hart and Copp have got it right in their justification of not lying etc. A teacher 
would be doing this if - implausibly, I agree - she took steps to prevent the learners from looking at alternative accounts.

You might say it is only a matter of differing linguistic preferences how one uses the word 'indoctrination'. On the other hand, indoctrinating is generally seen to be a bad thing, and some account of why this should be so is called for. What is wrong, in my view, is that indoctrination aims at preventing people from thinking for themselves and so threatens their intellectual autonomy and their wider personal autonomy that depends on this. This is why liberals typically find indoctrination abhorrent.

[b] I turn to three more crucial issues about children's acquisition of reasons.

First, Hand does not say how old the children he has in mind are. As things are in our world, children begin to be brought up not to lie, hit people, take others' belongings, or behave unfairly, well before they go to school, the message being reinforced during the primary years. It looks as Hand must be thinking of children between, say, two or three years old and nine or ten.

The Hartian justification is a piece of sophisticated philosophy. Is it intelligible to children of this age? To understand it, they would at least have to have something like a second-order grasp of what in general it is to be a human being, and of the notion of any human society. For the youngest children among them this would seem out of the question; and only the budding Collingwoods and Bertrand Russells among the oldest would seem able to gain some kind of handle on the argument, although Hand's kind of moral education is meant to be for all, or virtually all children.

On the face of it, Hand's approach to moral education seems inappropriate for younger children like these. But there might be several ripostes to this. One could be that we are in danger of underestimating young children's intellectual powers. Teachers involved in 'philosophy for children' often produce surprising examples of the interest pupils of even five or six are said to take in philosophical discussions of topics like friendship or what it is to be a human being. A second response might 
acknowledge that we could not expect all children to grasp the Hartian justification with all the acumen of a professional philosopher, but that it can be introduced to them in a simplified and age-appropriate way, perhaps with refinements added as they grow older.

I have problems with the first of these defences, evident from critiques of philosophy for children that I have published elsewhere (White 1992, 2012). On the second, I would find it hard to make a definitive judgment without seeing more details of how the pedagogy would work. For instance, the simplified version of the Hartian argument must at least be such as to be non-distorting, and I am not clear whether this is possible, given the importance in it of second-order considerations.

The second issue is about how far this understanding of Hartian reasons will take children in their moral learning. The latter is not just, if it is at all, an intellectual enterprise. In day-to-day living, it is not enough to know why telling the truth or helping someone in dire distress (etc) is something that we ought to do. Indeed, these things may not always be something that we ought to do, given that sometimes breaking a promise or hurting someone may occasionally be the right action, if moral considerations clash. Children have to learn how to apply rules, not only how rules are justified. They have to acquire judgment.

Hand may reply that all he wants to do is provide a general framework for moral education within which teachers can work: within this framework, teachers can draw children's attention to such things as conflicts of principle and how to handle these. But this answer would reveal the excessive thinness of Hand's 'theory of moral education'. It is an account that leaves out most of the substance of the topic and gives teachers minimal guidance.

The third issue brings us to the free rider. In a passage already quoted, Hand writes: 'Since all of us who live in social groups have an interest in averting breakdowns of cooperation and outbreaks of conflict, so we all have an interest in holding ourselves and others to rules of conduct that sustain cooperation and peace' (529). Suppose an articulate student in a Hand-based moral education programme says 'I can see why if there were no rules forbidding things like breaking promises and stealing, social 
life would break down, but if I steal sweets from the newsagents after school that won't cause such chaos. So the likelihood of social breakdown is not a reason for me not to steal, however cogent a reason it might be in some more general way. I don't have an interest in holding myself to a rule of conduct like this one.' Since, on Hand's view, moral education involves giving learners reasons why they should follow moral rules, he needs to say more than he does.

(c) Wider perspectives

As well as the question 'can young children grasp this justification?', we can also ask 'is it necessary for them to do so?' This brings us back to the issue left hanging earlier, about whether the desirability of social survival is the only starting point for a sound moral education, or whether there might be others.

Suppose we take a familiar situation from the very early moral education that parents provide for their pre-school children at home. Three-year-old Jason has pushed his toddler sister Alice over and made her cry. 'Don't do that, Jason,' says his mother. 'Look, you've hurt her. Give her a cuddle to make it better.' ${ }^{2}$

Here we have one of Hart's 'forbearances': refraining from physical harm to others. The mother has provided Jason with a reason for this: he has caused his sister pain. The justification is in terms of her well-being. This is reinforced by the suggestion of a cuddle and making things better for her.

Embedded in this homely argument is a basic assumption that what matters morally is other people's well-being. This is something that should be cherished and protected, not diminished or put at risk. This prompts the question: could this consideration not be the point of departure for moral education, wherever it takes place, rather than the one to do with social survival?

It would seem to apply not only to refraining from physical harm to others, but also to the other items in Hart's list. Why is it wrong to steal - 
to burgle someone's house, for instance? Anyone who has been burgled knows about the diminution of well-being that this causes - to do not only with the loss of goods vital to one's day-to-day existence, but also with the disruption, the hassle of putting things right, the fear that this might happen again. Lying, similarly, is bad for the other because it leads her to base her behaviour and view of the world on false beliefs, and is a risk to a relationship, intimate or collegial, based on mutual trust. Breaking a promise undermines expectations that the other has woven into her life, and is also a breach of trust.

The well-being starting point, like the social survival one, can lead to further demands for justification. 'One ought to care for others' wellbeing' is not a self-evident truth. It can be defended on the grounds that 'One ought to care for people's well-being, including one's own', but beyond that it is hard to know what to say. If someone claims that this last injunction is based on something like 'One ought to care for the wellbeing of all living creatures', would this cover the well-being of malariabringing mosquitoes or other dangerous pests? If not, is this because we take it for granted that morality is an institution created above all (but perhaps not solely) with the needs and circumstances of human beings in mind? If so, its point or function is not too far removed, on this view, from the Hartian belief in the importance of social survival.

Is there anything to choose between the well-being and the survival starting points for morality and for moral education? A telling argument for the former is that it does not restrict basic moral standards to forbearances, but allows them to include more positive prescriptions. We saw one of these at work in the story of Jason and Alice, when the mother told Jason that he should do something to make his sister's life better. Other examples fall in the area of helping those in need, which we saw raised problems for Hand's account. It is also through making links with a concern for others' well-being that we bring children up to think they should be friendly, approachable, dependable, kindly, fair in their dealings with them. At a more impersonal level, it is in the same way that we develop their wider, civic sensitivities - their concern, for instance, that the needy in their own society and beyond should have better incomes, housing, education. 
Another argument in favour of the well-being starting point over the social survival one is that the latter looks as if it has to be grounded in the former. For it is not just any kind of survival that Hartians advocate, including a bare clinging on to social life in the most distressing of conditions. The continued existence of society is important so that together we can make our lives more bearable than they otherwise would be. This is a well-being consideration. ${ }^{3}$

One argument against the well-being position might be that the notion of 'well-being' is controversial, so that appeals to how someone's well-being will or might be affected by one's lying or hitting could not fall under 'directive moral enquiry' but would have to belong to the non-directive kind.

The reply to this is that although some aspects of the notion are radically disputed (eg whether from a second-order perspective it is or is not to be understood in terms of desire-satisfaction), others are not. There would be general agreement that people's well-being suffers if they are hungry, in pain, have no income, have their plans thwarted etc.; and it is these kinds of misfortune that are at issue in this debate.

3. Hand's distinction between moral education and education for altruism

Section 2 has cast doubt on several aspects of Michael Hand's theory of moral education, including the scope of the prescriptions it enjoins, its justificatory basis in the social survival argument, and its appropriateness for younger children. In its place, Section 2 has suggested an account of moral education that avoids these difficulties and is rooted in caring for people's well-being.

The arguments and counter-arguments presented so far are also relevant to a discussion of the second of Hand's recent essays on moral education, his 'Beyond moral education?' (Hand 2014a), which he contributed to a book about new perspectives on my own work. ${ }^{4}$

Hand takes as his text Chapter 3 of my Education and the Good Life 
(White 1990), entitled, like Hand's critique of it, 'Beyond moral education?'. He focuses on a 'radical proposal' that he sees me making in the chapter, a recommendation 'that we abandon moral education in favour of 'education in altruism' (Hand 2014a: 99, quoting White 1990: 49 (but without the inverted commas I had importantly put round 'moral education').

By 'education in altruism' I had in mind the development of dispositions marked by concern for other people's well-being. Hand agrees that there is room in children's upbringing for education in altruism, but does not see this as replacing moral education (p.99). He says that children should be 'routinely moved to act, or refrain from acting, both by concern and sympathy for others and by a sense of moral right and wrong'. In place of what he calls my 'supersession' thesis, he goes on to defend a 'complementarity' thesis about the proper relationship between the two approaches.

He then goes on to examine and reject two sets of reasons he sees me as advocating for abandoning moral education. He calls the first 'uncertainty objections' and the second 'unloveliness objections' (101).

Uncertainty objections all have to do with the belief that 'critical moral philosophy has failed to vindicate an agreed moral code'. I will come back to some of these later, as here I only want to indicate the main lines of Hand's position for fear of getting too immersed in details. His main response is that there is, after all, an agreed set of moral standards, that is, those justified by the Hartian argument examined in a previous section.

Unloveliness objections are about the view that morality rests on a stern conception of human life as endlessly hemmed in by rules and dominated by feelings of guilt and shame (pp.105-6). More precisely, this is true of a 'maximalist' morality, where moral obligations fill virtually one's whole life. But morality can also take an - equally unlovely - 'minimalist' form in which one spends virtually the whole of one's time looking after one's own self-interest. Again, I will come back later to the details of what Hand says about unloveliness. His main response here is that Hartian morality 
does not bring with it the stern requirements that morality, on my view, is said to involve.

These are the bones of Hand's critique. I think it is off target. It presents me as saying that we should no longer teach children basic moral rules about not lying, stealing, physically harming and so on - but that this has to be replaced by an upbringing in altruistic dispositions. But I do not say this. What I do say is that these rules are so fundamental that every society needs them (p.21,37), and I itemise dispositions not to lie, break promises, harm people physically or mentally in the list of dispositions that I think should constitute an education in altruism (p.47, items 7 and 9).

My argument is not, therefore, that education in altruism should replace moral education as Hand understands it, but that it should incorporate it. It does this by giving not lying (etc) a rationale in terms of the protection or promotion of people's well-being and building up dispositions directed towards these. We saw an example earlier in the tale of Jason and Alice, where the mother wants her little boy to see that he should not push his sister over because this makes her cry, and that he should now give her a cuddle. She wants to build up in Jason good habits both of refraining from wrongdoing of this sort and of keeping other people's well-being in mind.

It may seem somewhat surprising that Hand does not recognise that I am arguing not for replacement but for incorporation, since he himself draws attention (pp. 104-5) to my acknowledgment of basic moral rules in the passages mentioned above from my pages 37 and 47 . But he underplays their significance for me, as is clear from his comment on the point made in the p.37 passage that White 'seems quickly to set it aside in pursuit of his larger thesis', and from his characterisation of the $p .47$ passage as 'a half-hearted attempt' to subsume adherence to basic moral rules under an altruistic disposition. My interest in subsuming them in this way was and is wholly whole-hearted.

My main target of criticism in my 1990 chapter is close to what Bernard Williams (1985, chapter 10), writing a few years before myself, called 'morality, the peculiar institution'. I discuss at some length how the 'traditional ways of conceiving morality' that have been part of a Christian 
heritage have been dominated by the notion of law, and my remarks about a stern, rule-filled view of human life mentioned in Hand's remarks about the 'unloveliness objections' have this kind of moral outlook in mind. I also indicate that less stringent versions of this law-based legacy continue to be influential down to our own times and have affected how we see education in this area. I often use the words 'moral' or 'morality' in an unqualified way to label these and other aspects of this tradition. A particularly prominent example is the chapter title itself: 'Beyond Moral Education?' Another is in the sentence, already partially quoted above, that Hand uses as springboard for his critique: 'What is lost or gained by abandoning 'moral education' for education in altruism?' (p.49). (Note again the significance of the inverted commas around abandoning 'moral education').

In none of this do I mean to repudiate the importance of basic moral rules (in a more ordinary sense of the term) about not killing, non-injury and so on. I see them as a framework, partially reflected in a legal system, within which a communal life in accordance with the virtues can flourish. Educationally, there is everything to be said, as I have already pointed out, for assimilating children's induction into these rules with education in the altruistic virtues.

I am glad Michael Hand has afforded me this opportunity of setting the record straight on where I stand on the meaning(s) of 'morality'. Substantively, he and I agree on the central point at issue, about the place of basic moral rules and of the virtues in a defensible ethical education (to use a neutral if awkward term that one of us may prefer to label 'moral education', and the other 'education in altruism'). Both of us make room for both of them.

I relegate to the Notes a brief discussion of two further points of interest in our debate. These are about 1. internal and external reasons, and 2. the idea of a minimalist morality. Hand raises these topics in his sections on 'uncertainty objections' and 'unloveliness objections' respectively. ${ }^{56}$

There are other minor ways in which I feel I must put the record straight about Hand's point (p. 106), for instance, that I object to a maximalist morality partly because it fills one's life with feelings not only of guilt but 
also of shame. In fact, it is only guilt that troubles me, as this is a reaction to breaking a rule, whereas shame is not to be understood in terms of rule-transgression.

But I do not want to conclude this piece with details like this, but with a reminder of the central point of my reply to Hand's critique. This is that I reject his suggestion that I see education in altruism as superseding moral education, while he sees the two as compatible. In fact, I distance myself from both of these. For me, education in altruism and moral education are not two distinct phenomena, as they would have to be if they were compatible. Rather, I see the former as incorporating acceptable aspects of the latter. ${ }^{7}$

\section{Notes}

${ }^{1}$ These writers also include Warnock (1971) and Mackie (1977). The four writers all have different projects and other differences of emphasis. Mackie in the end rejects the notion of an objective basis for ethics. Copp's interest is in the social function of different normative systems, like etiquette, morality and law. For a comment on Warnock, see note 3 below. Here I base what I say mainly on Hart's formulation as the classic account of this kind of justification. Describing the issue in Copp's formulation - of 'the problem of sociality' (Hand p.528) - does not seem to me materially to affect the main line of argument or considerations that can be brought against it.

${ }^{2}$ This everyday example prompts a further thought about the adequacy of Hand's overall theory. As we saw on $\mathrm{p} . \bullet$, he makes what seems to be a clearcut distinction between 'moral formation' and 'moral enquiry'. But the enterprise of giving and understanding reasons in this domain is not separable in practice from the day-to-day experience of correcting and improving 
children's behavior: much of this, as in this example, has to do with giving reasons.

${ }^{3}$ Warnock (1971: 57-8) links the making of moral judgments basically to the (supposed) 'good or harm, well-being or otherwise, of human beings'.

${ }^{4}$ I am grateful to the three editors of Suissa et al. (2014) for encouraging their authors to be critical of my arguments, and to Michael himself for his own trenchant piece. I am very pleased to be able to carry on the debate, and not least in this journal, which since its inception has welcomed responses and counter-responses to its articles.

5 'Internal reasons' for action, as I used the expression in White 1990: 56, include reference to the agent's desires. External reasons are not desiredependent in this way. Hand's position, contra mine in 1990, is that moral reasons, despite being reasons for action, are external (p.105): I should not kill someone, for instance, even though I have no desire to adhere to this prohibition.

I am now more persuaded than I was that reasons for action do not refer to one's desires. Instead, they refer to values. I read a poem not because poetry reading is among my informed desires, but because of the aesthetic and other values which it reveals to me. So I can agree with Hand that moral reasons are external. But, as I explained earlier, my position is that we should refrain from lying, hitting people, etc not because there are moral rules against these things tout court, but because such actions are deleterious to others' well-being, the latter constituting an external reason. I should add that I no longer understand 'well-being' in terms of the satisfaction of informed desires, as I did in 1990, but as involving engagement in worthwhile relationships and pursuits (White 2011: ch.8). Hence well-being reasons for action now become external ones.

${ }^{6}$ A 'minimalist morality', as I used the term in White 1990: 43-5, is one built around prohibitions and the prescription to help those in dire distress around one. I criticised it on the grounds, alluded to above (p.*), that it is compatible with a less than admirable approach to life, whereby one can spend virtually all one's time on one's own personal ambitions and enjoyments with minimal concern for others' well-being (unlike in education for altruism).

Hand builds into my notion of 'minimalist morality' something that I did not put there. He sees the personal ambitions and enjoyments just mentioned as 
concerned with 'maximising our utility' (p.106), and with satisfying 'the inclinations of the flesh' (p.107). His objection to 'minimalist morality' is in its 'narrow concern with maximising our utility' (p.108). He goes on: 'we need to rediscover and reinvent ends and activities capable of giving our lives meaning beyond the self-interested pursuit of pleasure. We need to rid ourselves of the idea that, once our moral obligations are discharged, there is nothing left except to feather our nests and recline in them'.

But I say nothing, in fact, about utility maximisation or the inclinations of the flesh. (The first idea is from Gauthier, not me (p.106); and the second comes from something I wrote later than White 1990 and not at all connected with moral minimalism (this is quoted in Hand's reference to White 1997 on p.107)). I find this minimalism an unattractive ideal for a human life for different reasons from Hand. He seems to disapprove only of its hedonistic aspects, thus leaving open the possibility of an acceptable minimalism in which a person spends virtually all their time and thought on higher pursuits. For me, whether the minimalist is a seeker after physical pleasures or a lover of classical music or philosophy, their failing is that they are insufficiently concerned about helping others to lead flourishing lives. This is why I have emphasised an education in the altruistic virtues.

${ }^{7}$ I am grateful to Patricia White for her comments on an earlier draft. Some of the most cogent points in this one have come from her.

\section{References}

Copp, D. (2009) 'Toward a Pluralist and Teleological Theory of Normativity', Philosophical Issues, 19: 1, pp. 21-37

Hand, M. (2014a) 'Towards a Theory of Moral Education', Journal of Philosophy of Education, 48: 4, pp. 519-531

(2014b) 'Beyond Moral Education?' in Suissa, J., Winstanley, C. and Marples, R. (eds) Education, Philosophy and Wellbeing: new perspectives on the work of John White London: Routledge 
Hart, H.L.A. (1961) The Concept of Law Oxford: Clarendon Press

Mackie, J.L. (1977) Ethics: Inventing Right and Wrong (Harmondsworth: Penguin)

Suissa, J., Winstanley, C. and Marples, R. (eds) (2014) Education, Philosophy and Well-being: new perspectives on the work of John White London: Routledge

Warnock, G.J. (1971) The Object of Morality London: Methuen

White, J. (1990) Education and the Good Life: Beyond the National Curriculum, London: Kogan Page

----- $\quad$ (1992) 'The Roots of Philosophy' in Griffiths, A.P. (ed) The Impulse to Philosophize Cambridge: Cambridge University Press, pp.73-88

------ (1997) 'Three proposals and a rejection' in Smith, R. and Standish, P. (eds) Teaching Right and Wrong: Moral Education in the Balance Stoke-on-Trent: Trentham, pp.15-27

------ $\quad$ (2012) 'Philosophy in Primary Schools' Journal of Philosophy of Education, 46: 3, pp.449-460

Williams, B.A.O. (1985) Ethics and the Limits of Philosophy, London: Fontana 